\title{
PHYSICOCHEMICAL PROFILE AND SENSORY EVALUATION OF CAKES WITH FLAXSEED AND YACON FLOUR ASSOCIATED TO SWEETENERS
}

\author{
NATÁLIA TODESCHINI ALMEIDA * \\ HELENA SCHMIDT * \\ VIVIANI RUFFO DE OLIVEIRA **
}

\begin{abstract}
The objective of this study was to evaluate the chemical, physical and sensory characteristics of cakes made with yacon and flaxseed flour as an alternative for patients with Diabetes. Four cakes were prepared: standard cake (CS) - yacon flour, flaxseed flour and sugar; cake A (CA) - yacon flour and flaxseed flour; cake B (CB) - yacon flour, flaxseed flour and sucralose and acesulfame-k; cake C (CC) - yacon flour, flaxseed flour and stevia. Moisture, carbohydrates, proteins, lipids, dietary fiber, ash and energy value of the products were evaluated. For the physical analysis were determined before and after cooking weight and height, and thermal factor. For sensory analysis, 40 untrained people evaluated appearance, color, texture, flavor, overall acceptability and purchase intention. All the cakes had great fibers intake. The cake with more calories and carbohydrate content was CS. This cake also had a higher weight before and after cooking. In sensory evaluation, the cakes did not showed significant differences in appearance and color. In flavor attributes, overall acceptance and in intention to purchase, CS and CB were better accepted. Thus, it can be concluded that the cake with yacon and flaxseed associated to sucralose and acesulfame-k is a good alternative for patients with Diabetes mellitus due to functional properties and good fiber content.
\end{abstract}

KEY-WORDS: CAKES; SWEETENERS; Polymnia sonchifolia; Linum usitatissimum L.

* Nutricionistas, Curso de Nutrição, Universidade Federal do Rio Grande do Sul (UFRGS), Porto Alegre, RS, Brasil (e-mail: natialmeida@hotmail.com; helena_schmidt@hotmail.com).

** Professor Adjunto, Departamento de Medicina Interna, Curso de Nutrição, UFRGS, Porto Alegre, RS, Brasil (e-mail: vivianiruffo@hotmail.com). 


\section{INTRODUCTION}

Diabetes mellitus (DM) is a chronic disease characterized by the lack of pancreas insulin production or the inadequate action of this hormone, in which hyperglycemia is the main effect (WHO, 2003). In the long term, this increase in blood glucose can cause eye, renal, neural and cardiac damage (SILVA \& MURA, 2007). To control blood glucose is important to adopt healthy habits, such as physical activity and healthy food (WHO, 2003), especially replacing refined sugars by whole, reducing fat intake and increasing dietary fiber (SILVA \& MURA, 2007).

Yacon (Polymnia sonchifolia), originally from the Andes, has a sweet taste and present a high content of fiber and fructo-oligosaccharides (FOS) (MOSCATTO et al., 2004) that can improve lipid profile and help in bowel function (MEIER \& LOCHS, 2007). Besides yacon is considered a low glycemic index $(\mathrm{Gl})$ food, its consumption is associated to a lower postprandial glycemic response (OLIVEIRA et al., 2009).

Flaxseed (Linum usitatissimum L.) contains a high fiber amount and essential fatty acid (EFA) omega-3 (SALES, 2009), that is related to glycated hemoglobin (HbA1c) decreasing concentrations in patients with type 2 diabetes (PAN et al., 2007).

Considering that Diabetes mellitus is a high prevalence disease in Brazil and in the world, it is relevant to find alternative formulations that enable these patients to consume sweet food as a way to overcome the desire to ingest them, promoting sociability. Furthermore, the formulation of a sweetened product associated to an increase in dietary fiber content, besides being a challenge, allows diabetic patients to find new products options to avoid monotony, severe restriction of food and to monitor blood glucose levels control.

The aim of the present study was to make cakes with flaxseed and yacon flour for patients with Diabetes mellitus and analyze the physical, chemical and sensory characteristics of the products.

\section{MATERIAL AND METHODS}

Flour and cakes preparation, as well as the physical and sensory analysis occurred in the Dietetics Laboratory of the Nutrition Course at Medicine School (FAMED) of Universidade Federal do Rio Grande do Sul (UFRGS). The chemical analysis was performed in Bromatology Laboratory of the Instituto de Ciência e Tecnologia de Alimentos (ICTA) at UFRGS.

\subsection{FLAXSEED AND YACON FLOUR PREPARATION}

It was used dehydrated yacon from Takashi Kakihara Cia manufacturer, located in Rio de Janeiro (Brazil). Yacon was first ground in a blender Philips ${ }^{\circledR}$, model RI2044, and then sieved to get the yacon flour. Brown flaxseed flour was also acquired through grinding, in a blender Philips $₫$ model RI2044, and sieving.

\subsection{CAKES FORMULATIONS}

Four cakes were made: standard cake (CS) - yacon flour, flaxseed flour and sugar; cake $A(C A)$ - yacon flour and flaxseed flour; cake B (CB) - yacon flour, flaxseed flour and sucralose and acesulfame-k; cake C (CC) - yacon flour, flaxseed flour and stevia. These sweeteners were chosen because they can be submitted to high temperature. All the ingredients and their quantities used in the samples are specified in Table 1.

For the cakes preparation all the ingredients were weighed on a digital balance Filizola ${ }^{\circledR}$, Pluris Top model. After, all the ingredients except the yeast were mixed in a blender Top Mixer model, for five minutes, using velocity two. Finally, the yeast powder was added to be mixed by hand until 
incorporate completely into the cake. The cake was put in a rectangular form greased with $5 \mathrm{~mL}$ of vegetable oil, and baked at $200{ }^{\circ} \mathrm{C}$ for 40 minutes.

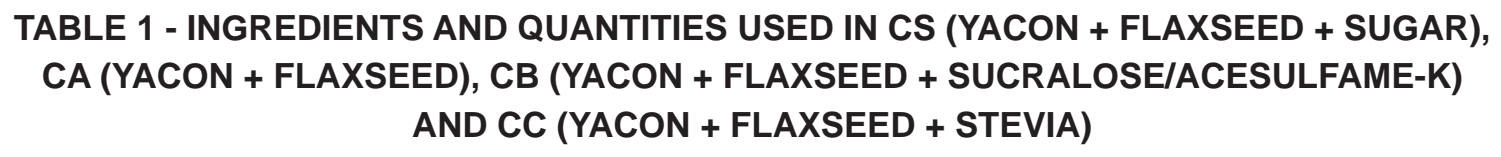

\begin{tabular}{lcccc}
\hline \multirow{2}{*}{ INGREDIENTS } & \multicolumn{4}{c}{ CAKES TREATMENTS } \\
\cline { 2 - 5 } & CS & CA & CB & CC \\
\hline Wheat flour (g) & 130 & 130 & 130 & 130 \\
Yacon flour (g) & 100 & 100 & 100 & 100 \\
Flaxseed flour (g) & 30 & 30 & 30 & 30 \\
Sugar (g) & 90 & ---- & ---- & --- \\
Sucralose/acesulfame-K (9 g) & ---- & ---- & 4,8 & ---- \\
Stevia (g) & ---- & ---- & --- & 5 \\
Whole milk (mL) & 125 & 125 & 125 & 125 \\
Egg (g) & 46 & 46 & 46 & 46 \\
Vegetal oil (mL) & 20 & 20 & 20 & 20 \\
Yeast powder (g) & 20 & 20 & 20 & 20 \\
\hline
\end{tabular}

\subsection{CHEMICAL ANALYSIS}

The analysis of moisture, protein, lipids and ash were taken in triplicate following regulations of Instituto Adolfo Lutz (1985). The carbohydrates were evaluated by the difference between $100 \mathrm{~g}$ of cake and the total sum of the values analyzed (CARVALHO \& JONG, 2002). The fibers of the ingredients were purchased through the values of dietary fiber related in Brazilian Table of Food Composition (TACO, 2006) - version 2. To determine the caloric value of $100 \mathrm{~g}$ of the cake, were used the values stipulated by RDC $\mathrm{n}^{\circ} 360$ of 2003, being $4 \mathrm{kcal}$ to $1 \mathrm{~g}$ of carbohydrate, $4 \mathrm{kcal}$ for $1 \mathrm{~g}$ of protein and $9 \mathrm{kcal}$ for $1 \mathrm{~g}$ of fat. These values were multiplied by the values found for these macronutrients, and finally was summed to obtain the caloric value in the portion (BRASIL, 2003).

\subsection{PHYSICAL ANALYSIS}

To evaluate cake weight, first was weighed the form used for the cakes and after the cake before cooking. The form were weighed in a balance Filizola ${ }^{\circledR}$, Pluris Top model, and finally was discounted the value of the form. The same procedure was performed with the cake already baked (GUIMARÃES, FREITAS \& SILVA, 2010).

To determine height before cooking, a point was marked in the form using a pen, and then was measured with a ruler. The height after cooking was determined at the same way, after removing the cake from the oven (ARAÚJO et al., 2009).

\subsection{SENSORY ANALYSIS}

For sensory analysis were randomly recruited at the UFRGS, 40 non-diabetic and nontrained judges, which were students and employees of the university.

To each judge was supplied a slice of $12 \mathrm{~g}$ of each one of the four samples with a sensory evaluation form. It was used a scale ranging from 1 (dislike extremely) to 9 (like extremely) points to 
evaluate the attributes of appearance, color, texture, flavor, and global acceptance (DUTCOSKI, 1996). The samples were presented monadically following a completely randomized design. Mineral water and salt cookies were available as neutralizers between the samples in order to avoid carryover effects.

An assessment related to the consumers' purchase intention was also carried out regarding the four cakes samples. A 5-point scale was used, in which 1 indicated that the consumers definitely would not buy; 2 consumers would probably not buy; 3 consumers may/may not buy; 4 consumers would probably buy and 5 consumers would definitely buy (STONE \& SIDEL, 1993).

\subsection{ETHICS ASPECTS}

This study was approved by the Ethics Committee of Universidade Federal do Rio Grande do Sul (UFRGS), registered under Protocol number 20348, and all the participants signed a consent form, according to the norms of CNS/MS Resolution 196/96 (BRASIL, 1996).

\subsection{STATISTIC ANALYSIS}

The experimental design was entirely randomized, and the data obtained in the physicochemical and sensory analysis were submitted to ANOVA and Tukey's test to compare the averages among the samples at a $5 \%$ significance level. Statistical Analysis ESTAT version 2.0 was used for data analysis (ESTAT, 1992).

\section{RESULTS AND DISCUSSION}

\subsection{CHEMICAL ANALYSIS}

As shown in Table 2, all cakes presented significant differences $(p<0.05)$ between samples for moisture content. Rosa et al. (2009), in a study evaluating cakes also made with yacon flour, found an average value of moisture of $35 \%$. Borges et al. (2011) observed that FOS and the flaxseed fiber interact with water, and showed difficulty in evaporation during cooking.

TABLE 2 - CHEMICAL COMPOSITION OF THE CAKES: CS (YACON + FLAXSEED + SUGAR), CA (YACON + FLAXSEED), CB (YACON + FLAXSEED + SUCRALOSE AND ACESULFAME-K) AND CC (YACON + FLAXSEED + STEVIA)

\begin{tabular}{lcccc}
\hline \multirow{2}{*}{ CHEMICAL COMPOSITION } & \multicolumn{4}{c}{ CAKES TREATMENTS } \\
\cline { 2 - 5 } & CS & CA & CB & CC \\
\hline & & & & \\
Moisture (\%) & $28.92^{\mathrm{d}}$ & $34.19^{\mathrm{b}}$ & $33.72^{\mathrm{c}}$ & $35.46^{\mathrm{a}}$ \\
Proteins (\%) & $6.8^{\mathrm{b}}$ & $7.86^{\mathrm{a}}$ & $7.83^{\mathrm{a}}$ & $7.7^{\mathrm{a}}$ \\
Lipids (\%) & $4.08^{\mathrm{d}}$ & $7.61^{\mathrm{a}}$ & $6.81^{\mathrm{c}}$ & $7.44^{\mathrm{b}}$ \\
Carbohydrates (\%) & $53.66^{\mathrm{a}}$ & $43.8^{\mathrm{c}}$ & $44.89^{\mathrm{b}}$ & $42.81^{\mathrm{d}}$ \\
Fibers (\%) & $3.02^{\mathrm{a}}$ & $3.02^{\mathrm{a}}$ & $3.02^{\mathrm{a}}$ & $3.02^{\mathrm{a}}$ \\
Ash (\%) & $3.05^{\mathrm{d}}$ & $3.52^{\mathrm{c}}$ & $3.73^{\mathrm{a}}$ & $3.57^{\mathrm{b}}$ \\
Calories & $278.56^{\mathrm{a}}$ & $275.13^{\mathrm{b}}$ & $272.17^{\mathrm{c}}$ & $269.00^{\mathrm{d}}$ \\
& & & & \\
\hline
\end{tabular}

Means followed by same letter horizontally do not show a statistically significant difference $(p>0.05)$.

Maia (2007) in a study evaluating cakes made with passion fruit flour, saccharin and cyclamate, has found significantly higher moisture content in cakes prepared with sweetener. According 
to the author, this occurred because one of the sugar functions in butter cakes is to retain water.

The moisture in the cakes is related to the ingredients added to the butter, the time in the mixer and the cooking time (BAIK, MARCOTTE \& CATAIGNE, 2000), furthermore, according to Borges et al. (2006) it gives softness to the product, preventing that the cake becomes too hard.

According to Esteller, Zancanaro Júnior and Lannes (2006) the value of moisture in industrialized cakes should be around $30 \%$, because the excess of water can promote microbial growth and reduce cakes shelf life (OSAWA et al., 2009).

Related to protein, there was no significant difference $(p>0.05)$ between the cakes $C A, C B$ and CC. Only the cake CS showed significant difference $(p<0.05)$, being the lowest value. Oliveira et al. (2007) found approximately $8 \%$ of protein in breads made with flaxseed, being significantly higher than cakes without the addition of the seed. In inappropriate protein content, the gas retention may be impaired, leading to a compact and no volume cake (BORGES et al., 2006).

Regarding lipids, all cakes presented statistically significant difference $(p<0.05)$ between groups. Silva et al. (2010) when evaluating cookies made with different sweeteners (sugar, sucralose and acesulfame-k, stevia), also found significant higher amount of lipids in cookies made with stevia compared to those containing sucralose and acesulfame- $\mathrm{K}$.

In the carbohydrates analysis, the cake CS presented the highest content of this nutrient, showing a significant difference $(p<0.05)$ compared to the others. This result was obtained, because the cake CS was the only prepared with sugar. The other formulations also presented significant difference $(p<0.05)$ among them.

All formulations showed the same fiber content. This can be explained because the fiber content was used in the same amounts for the four formulations. Fibers are very important to diabetic people because their consume show benefic effects on glycemic and lipid control (WHO, 2003; MELLO \& LAAKSONEN, 2009) and can modify insulin resistance by increasing the sensitivity to this hormone (BURTON-FREEMAN, 2000).

Regarding the ashes, there was a significant difference $(p<0.05)$ among the cakes. Rosa et al. (2009) found a mean of $2 \%$ ashes in cakes made with flour yacon. Borges et al. (2011) also found an increase of ashes when added flaxseed flour in the breads composition. This fact can be attributed to the good mineral content present in this seed (COSKUNER \& KARABABA, 2007).

As for calories, all the cakes showed significant difference $(p<0.05)$ among them. The higher caloric intake was found in CS, because this cake contains sugar in its formulation. The cake CB possibly had a greater caloric value as compared with the $\mathrm{CC}$, because the sucralose and acesulfame-k used in this cake (CB) presents three calories every $0.8 \mathrm{~g}$ of product, while the stevia used in the $\mathrm{CC}$ has no calories. These data show, as those found in the Agarwal, Kochhar and Sachdeva (2009) study, that replacement of sugar by a sweetener in food production, provides a significant reduction in calories.

\subsection{PHYSICAL ANALYSIS}

Table 3 shows that the formulation CS presented the greatest value of before cooking weight being significant difference $(p<0.05)$ compared to the other cakes, this result probably occurred because it was added to the standard cake $20 \mathrm{~g}$ of sugar. The cake CC showed the lowest before cooking weight. After cooking, the cake CS obtained the greater weight, showing significant difference compared to the other formulations. This cake also has been the heaviest after cooking. Akesowan (2009) in a study replacing sucralose for sugar in cakes, found similar results, noting that as the sweetener was added to the baking, the cake lost weight and gained less height after cooking. According to this author, this was due to the reduced ability of sucralose to retain air.

Regarding the before cooking height, there was no significant difference $(p>0.05)$ between the cakes. One reason for this result was the fact that the four formulations followed the same time between the baking processing and the beginning of the cooking, so, the yeast powder acted similarly in cakes. 
TABLE 3 - PHYSICAL COMPOSITION OF THE CAKES: CS (YACON + FLAXSEED + SUGAR), CA (YACON + FLAXSEED), CB (YACON + FLAXSEED + SUCRALOSE AND ACESULFAME-K) AND CC (YACON + FLAXSEED + STEVIA)

\begin{tabular}{lcccc}
\hline & \multicolumn{4}{c}{ CAKES TREATMENTS } \\
\cline { 2 - 5 } PHYSICAL COMPOSITION & CS & CA & CB & CC \\
\hline Before cooking weight (g) & $534.0^{\mathrm{a}}$ & $454.0^{\mathrm{b}}$ & $452.0^{\mathrm{b}}$ & $436.0^{\mathrm{c}}$ \\
After cooking weight $(\mathrm{g})$ & $506.0^{\mathrm{a}}$ & $414.0^{\mathrm{c}}$ & $412.0^{\mathrm{c}}$ & $432.0^{\mathrm{b}}$ \\
Before cooking height (cm) & $2.51^{\mathrm{a}}$ & $2.52^{\mathrm{a}}$ & $2.50^{\mathrm{a}}$ & $2.46^{\mathrm{a}}$ \\
After cooking height (cm) & $4.12^{\mathrm{a}}$ & $3.57^{\mathrm{b}}$ & $3.4^{\mathrm{c}}$ & $4.07^{\mathrm{a}}$ \\
Thermal factor & $0.94^{\mathrm{b}}$ & $0.91^{\mathrm{b}}$ & $0.91^{\mathrm{b}}$ & $0.99^{\mathrm{a}}$ \\
\hline
\end{tabular}

Means followed by same letter horizontally do not show a statistically significant difference $(p>0.05)$.

After cooking, the cakes that were higher were the CS and CC with no significant difference $(p>0.05)$, while the cake which presented less height was the CB followed by $C A$, showing significant different $(p<0.05)$.

In breads and cakes, when sugar is replaced by another ingredient or withdrawn of the formulation, there may be the dilution of proteins that form gluten, which can lead to reduction in the specific volume and a modified texture of the mass (GOMEZ et al., 2003).

Regarding the thermal factor, the cakes $\mathrm{CA}$ and $\mathrm{CB}$ had the lowest value, having no significant difference $(p>0.05)$. However, significant difference $(p<0.05)$ was observed for $C S$ and $\mathrm{CC}$. Thus, the cake CA and CB have shown more yield after cooking.

\subsection{SENSORY ANALYSIS}

Table 4 shows that in regarding to appearance and color, the cakes presented no significant difference $(p>0.05)$ among them. The average of notes selected by the judges for these attributes were related to grade 7.0 ("like moderately"). According to Ornellas (2007), one of the functions of sugar is to improve the color and appearance of the cake during cooking, because at high temperatures this ingredient undergoes a process of caramelization, and can be considered a natural dye. However, the judges did not identify differences among cakes in relation to these attributes.

In relation to the texture, CS and CB presented higher averages point (7.65 and 7.40, respectively) with no significant difference $(p>0.05)$ between them. Sugar presented in $C S$ is related to improvement of cake characteristics, providing softness to the product (PHILIPPI, 2006; ORNELLAS, 2007).

The cake CC received score 7.12 to texture, with no significant difference $(p>0.05)$ in relation to the other cakes. The cake CA obtained the lower score 6.27 (like slightly), being statistically different $(p<0.05)$ in relation to CS and CB.

As for flavor, CS received the highest score (7.52), followed by CB (6.82), presenting no significant difference $(p>0.05)$ between them. The cake CC received score 6.02 ("like slightly"), being statistically different from CS and CA, but presenting no significant difference $(p>0.05)$ when compared to the CB. The cake CA obtained the lowest score (4.40) for the attribute flavor, presenting a significant difference $(p<0.05)$ compared to the other formulations.

According to Philippi (2006), sugar used to prepare CS is not only related to increasing the volume of the cake after cooking, but also provides a pleasant taste to the product. Furthermore, according to Oetterer et al. (2006), when subjected to higher temperatures, as in the present study, sugar tend to have higher sweetness. However, the refined sugar used in the cake is an ingredient with high glycemic index, being not healthy to patients with DM (SILVA \& MELLO, 2006). 


\section{TABLE4-SENSORYANALYSISOFTHECAKESCS(YACON+FLAXSEED+SUCROSE),CA(YACON \\ FLAXSEED), CB (YACON + FLAXSEED + SUCRALOSE AND ACESULFAME-K) AND \\ CC (YACON + FLAXSEED + STEVIA)}

\begin{tabular}{lcccc}
\hline \multirow{2}{*}{ ATTRIBUTES } & \multicolumn{5}{c}{ CAKES TREATMENTS } \\
\cline { 2 - 5 } & CS & CA & CB & CC \\
\hline Appearance & $7.27^{\mathrm{a}} \pm 1.74$ & $6.65^{\mathrm{a}} \pm 1.74$ & $7.10^{\mathrm{a}} \pm 1.74$ & $7.04^{\mathrm{a}} \pm 1.74$ \\
Color & $7.42^{\mathrm{a}} \pm 1.41$ & $6.82^{\mathrm{a}} \pm 1.41$ & $7.20^{\mathrm{a}} \pm 1.41$ & $7.20^{\mathrm{a}} \pm 1.41$ \\
Texture & $7.65^{\mathrm{a}} \pm 1.71$ & $6.27^{\mathrm{b}} \pm 1.71$ & $7.40^{\mathrm{a}} \pm 1.71$ & $7.12^{\mathrm{ab}} \pm 1.71$ \\
Flavor & $7.52^{\mathrm{a}} \pm 1.58$ & $4.40^{\mathrm{c}} \pm 1.58$ & $6.82^{\mathrm{ab}} \pm 1.58$ & $6.02^{\mathrm{b}} \pm 1.58$ \\
Purchase intent & $7.50^{\mathrm{a}} \pm 1.55$ & $5.02^{\mathrm{c}} \pm 1.55$ & $7.02^{\mathrm{ab}} \pm 1.55$ & $6.30^{\mathrm{b}} \pm 1.55$ \\
\hline
\end{tabular}

Means followed by same letter horizontally do not show a statistically significant difference $(p>0.05)$.

The satisfactory approval of cake CB for flavor can be explained because sucralose has a similar flavor to the sugar and present less after taste compared to other sweeteners (NACHTIGALL \& ZAMBIAZI, 2006). This result is extremely relevant, since sucralose can be used to replace sugar, without significantly changing in taste of cakes and even without altering serum glucose, than can be used by patients with DM (KROYER, 2006).

In a study evaluating simple cakes with differences only in sweeteners type (sugar, sucralose and acesulfame-K, stevia, saccharin and cyclamate), Biacchi (2006) found the same results of this study, the cakes formulated with sugar had the highest acceptance for texture and flavor. Cakes made with sucralose and acesulfame-K also received the highest scores for all attributes compared to the cakes made with stevia. This result may be associated with the noticeable residual taste of stevia. In the same study of Biacchi (2006), the cakes made with stevia were evaluated as more aftertaste, showing statistically difference compared to the other cakes formulated with sugar and sucralose and acesulfame-K. In another study evaluating cookies made with pumpkin flour and no sugar, Silva et al. (2010) also found higher scores to flavor in cookies made with sugar, followed by those with sucralose and finally for those containing stevia. For texture, the cookies with stevia received the lowest score when compared to other formulations. This result is also consistent with findings in the present study.

Referring to the global acceptance, CS received the highest score (7.5), followed by CB (7.02), with no significant difference $(p>0.05)$ between them. CC received average score of 6.3 , presenting no significant difference $(p>0.05)$ compared to $C B$, but differing from the other formulations.

The cake CA obtained the lower approval for global acceptance, with an average score of 5.02 , on the note "indifferent", presenting a significant difference $(p<0.05)$ for all formulations. This result demonstrates that the yacon use in isolation, has not presented pleasant flavor to the cake, needing to be used a sweetener to impart sweet taste to the product.

Silva et al. (2010) in a study with chocolate cakes plus with flaxseed flour, found similar scores for global acceptance between the standard cake and the cake containing flaxseed flour. This showed that cakes made with flaxseed flour were well accepted and that this ingredient can be used in cakes, as well as providing a good supply of fiber for consumers.

The results of global acceptance are consistent with those found for the attribute flavor. This suggests that the judges associated the global acceptance of the cakes, especially with the flavor that the product offers than the other attributes.

Figure 1 presents the results obtained for the purchase intention of the judges. The results were divided into three groups: purchase (referred to notes 4.0 and 5.0) in question (referring to the note 3.0) and not purchase (referred to notes 1.0 and 2.0). 
The cakes CS and CB were more acceptable and received more purchase intention. In relation to CS, $84.6 \%$ of judges would purchase this formulation, $7.69 \%$ were in question and $7.69 \%$ would not purchase this cake. As for CB, $58.97 \%$ said they would purchase the cake, $30.76 \%$ were in question and $12.82 \%$ would not purchase this formulation.

Referring to the cake CA, $12.82 \%$ pointed that they would purchase it, $17.94 \%$ were in question and $69.22 \%$ of the judges would not purchase this cake. For CC, $48.7 \%$ of the judges mentioned they would purchase it, $28.2 \%$ were in question and $23.06 \%$ would not purchase this formulation.

According to Guerrero et al. (2000), purchase intention is a decision process, which takes into account many factors such as price, convenience and product marketing, but the sensory attributes are determinants to purchase decision. This statement is consistent with the results found in the present study, since that the grate notes selected for sensory attributes for cakes made with sweeteners, reflected in the choice of purchasing these products.

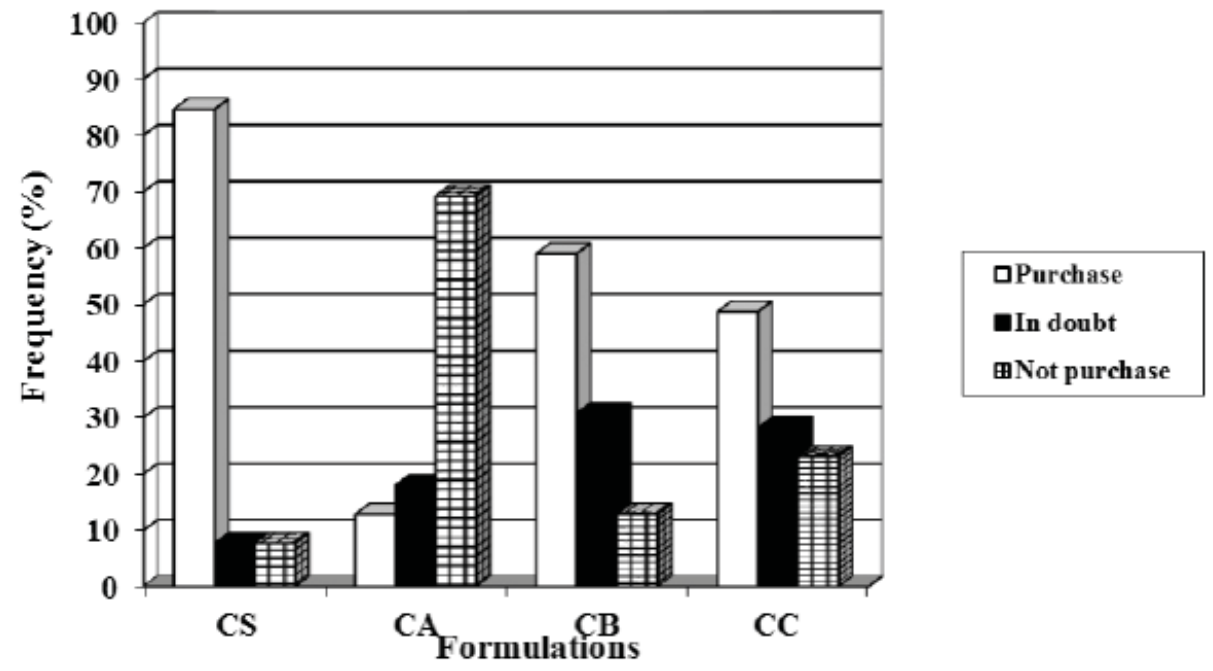

\section{FIGURE 1 - PURCHASE INTENT RELATED TO CAKES: CS (YACON + FLAXSEED + SUGAR), CA (YACON + FLAXSEED), CB (YACON + FLAXSEED + SUCRALOSE AND ACESULFAME-K) AND CC (YACON + FLAXSEED + STEVIA)}

The results found in purchase intention are in accordance to those determined for flavor and global acceptance, being CS and CB the better accepted, followed by CC and, finally, CA. According to Nachtigall and Zambiazi (2006) the flavor is a major quality criteria that influences the decision to purchase a product.

Sucralose and acesulfame-K did not interfere significantly in the sensory characteristics of the formulation. This result is relevant because this formulation seems to be a good alternative for patients with DM, which should avoid cakes made with sugar.

\section{CONCLUSION}

Yacon and flaxseed used in the formulations enabled a good supply of fiber to the cakes, and could be useful for healthy individuals and patients with DM. Moreover, the cakes made without sugar showed a lower caloric value, what is interesting for patients with DM, to keep an adequate weight for better disease control.

The cake made with yacon with no sweetener, did not seem to be a good alternative to sensory characteristics, showing that the yacon in this study did not favor the sweet taste of the cake, needing to use a sweetener in combination with that ingredient.

After the standard cake, the one made with sucralose associated to acesulfame-K was the best accepted in all attributes in sensory analysis. 


\section{PERFIL FÍSICO-QUÍMICO E ANÁLISE SENSORIAL DE BOLOS ELABORADOS COM FARINHAS DE LINHAÇA E YACON ASSOCIADAS COM EDULCORANTES}

O presente estudo teve como objetivo avaliar a composição química, física e as características sensoriais de bolos formulados com farinhas de yacon e de linhaça, como alternativa para pacientes com Diabetes mellitus. Foram elaborados quatro bolos: (P) farinha de yacon, farinha de linhaça e sacarose; (A) farinha de yacon e farinha de linhaça; (B) farinha de yacon, farinha de linhaça e sucralose/acessulfame-K; (C) farinha de yacon, farinha de linhaça e stévia. Os bolos foram avaliados quanto a umidade, carboidratos, proteínas, lipídeos, fibra alimentar, cinzas, valor energético, fator térmico, peso e altura pré e pós-cocção. Para a análise sensorial, 40 julgadores não treinados avaliaram os atributos aparência, cor, textura, sabor, e aceitação global, além da intenção de compra dos produtos. O bolo S apresentou maior valor calórico e teor de carboidratos. Esse bolo também evidenciou maior peso pré e pós-cocção. Na análise sensorial, os bolos não apresentaram diferença significativa quanto à aparência e cor. Para os atributos sabor, aceitação global e intenção de compra, o bolo padrão e o $\mathrm{B}$ foram os mais aceitos pelos julgadores. Conclui-se que o bolo com sucralose/acesulfame-K constitui boa alternativa para pacientes com Diabetes mellitus, devido às propriedades funcionais e ao bom aporte de fibras.

PALAVRAS-CHAVE: BOLOS; EDULCORANTES; Polymnia sonchifolia; Linum usitatissimum L.

\section{REFERENCES}

1 AGARWAL, V.; KOCHHAR, A.; SACHDEVA, R. Sensory and nutritional evaluation of sweet cereal products prepared using stevia powder for diabetics. Ethno-Med. v.3, n.2, p.93-98, 2009.

2 AKESOWAN, A. Quality of reduced-fat chiffon cakes prepared with erythritol-sucralose as replacement for sugar. Pakistan Journal of Nutrition, v.8, n.9, p. 1383-1386, Dec. 2009

3 ARAÚJO, W.M.V. et al. Alquimia dos alimentos. Brasília: Senac-DF, 2009.

4 BAIK, O.D.; MARCOTTE, M.; CATAIGNE, F. Cake baking in tunnel type multi-zone industrial ovens. Part II. Evaluation of quality parameters. Food Research International, Quebec, v. 33, n.7, p. 599-607, Aug. 2000.

5 BIACCHI, S.M. Análise qualitativa e sensorial de edulcorantes em bolo caseiro. 2006. 43 f. Monografia (Graduação em Nutrição) - Centro Universitário Franciscano, Santa Maria, 2006.

6 BORGES, J.T.S. et al. Utilização de farinha mista de aveia e trigo na elaboração de bolos. B. do CEPPA, Curitiba, v.24, n.1, p.145-162, jan./jun. 2006.

7 BORGES, J.T.S. et al. Caracterização físico-química e sensorial de pão de sal enriquecido com farinha integral de linhaça. B. do CEPPA, Curitiba, v.29, n.1, p.83-96, jan./jun. 2011.

8 BRASIL. Ministério da Saúde. Resolução 196/96 do Conselho Nacional de Saúde. Diretrizes e normas regulamentadoras de pesquisa envolvendo seres humanos. Diário Oficial [da] República Federativa do Brasil, Brasília, 10 de outubro de 1996.

9 BRASIL. Agência Nacional de Vigilância Sanitária. Resolução RDC n $^{\circ}$ 360, de 23 de dezembro de 2003. Sobre rotulagem nutricional. Publicada em 26/12/2003. Disponível em: <http://e-legis.bvs.br/leisref/public/php/home.php>. Acesso em: 19 de março de 2011.

10 BURTON-FREEMAN, B. Dietary fiber and energy regulation. J. Nutr., Thousand Oaks, v.130, n.2, p.272-275, Fev. 2000.

11 CARVALHO, H.; JONG, E.V. Alimentos: métodos físicos e químicos de análise. Porto Alegre: ed. UFRGS, 2002. v.1.

12 COSKUNER, Y; KARABABA, E. Some physical properties of faxseed (Linum usitatissimum. L.). Journal of Food Engineering, Mersin, v.78, n.3, p.1067-1073, Feb. 2007.

13 DUTCOSKI, S.D. Análise sensorial de alimentos. Curitiba: Champagnat, 1996.

14 ESTAT 2.0. Sistema de análise estatística. Jaboticabal: Polo Computacional, Departamento de Ciências Exatas, UNESP, 1992.

15 ESTELLER, M.S.; ZANCANARO JÚNIOR, O.; LANNES, S.C.S. Bolo de "chocolate" produzido com pó de cupuaçu e kefir. Revista Brasileira de Ciências Farmacêuticas. São Paulo, v.42, n.3, p. 447-454, jul./set.2006.

16 GOMEZ, M. et al. Effect of dietary fiber on dough rheology and bread quality. European Food Research and Technology, Witzenhausen, v.216, n.1, p.51-56, Aug. 2003.

17 GUERRERO, L. et al. Consumer attitude towards store brands. Food Quality and Preference, Monells, v.11, n.6, p.387- 
395, Mar. 2000.

18 GUIMARÃES, R.R.; FREITAS, M.C.J.; SILVA, V.L.M. Bolos simples elaborados com farinha da entrecasca de melancia (Citrullus vulgaris, sobral): avaliação química, física e sensorial. Ciênc. Tecnol. Aliment., Campinas, v.30, n.2, p.354363, abr/jun. 2010.

19 INSTITUTO ADOLFO LUTZ. Normas analíticas do Instituto Adolfo Lutz. 3. ed. São Paulo: IMESP, 1985. v.1

20 KROYER, G. Stevioside and stevia-sweetner in food: application, stability and interaction with food ingredients. J. Verbr. Lebensm., Wien, v.5, n.2, p.225-229, Jan. 2010.

21 MAIA, S. M. P. C. Aplicação da farinha de maracujá no processamento do bolo de milho e aveia para fins especiais. 2007. 78 f. Dissertação (Mestrado em Tecnologia de Alimentos), Universidade Federal do Ceará, Fortaleza, 2007.

22 MEIER, R.; LOCHS, H. Pre and probiotics. Rev. Therapeut., v. 64, n. 3, p. 161-169, 2007.

23 MELLO, V.D.; LAAKSONEN D.E. Fibras na dieta: tendências atuais e benefícios à saúde na síndrome metabólica e no diabetes melito tipo 2. Arq. Bras. Endocrinol. Metab., São Paulo, v.53, n.5, p.509-518, jun. 2009.

24 MOSCATTO, J.A. et al. Farinha de yacon e inulina como ingredientes na formulação de bolo de chocolate. Ciênc. Tecnol. Aliment., Campinas, v.24, n.4, p.634-640, out./dez. 2004.

25 NACHTIGALL, A.M.; ZAMBIAZI, R.C. Geléias de hibisco com reduzido valor calórico: características sensoriais. Boletim do CEPPA, Curitiba, v.24, n.1, p.47-58, jan./jun. 2006.

26 OETTERER, M. et al. Fundamentos de ciência e tecnologia dos alimentos. São Paulo: MANOLE, 2006. p. 612.

27 OLIVEIRA, T.M. et al. Elaboração de pão de sal utilizando farinha mista de trigo e linhaça. Alim. Nutr., Araraquara, v.18, n.2, p.141-150, abr./jun. 2007.

28 OLIVEIRA, V.F. et al. Frutanos em calos de Smallanthus sonchifolius (Poepp.) H. Rob. Hoehnea, São Paulo, v.36 n.1, p.89-97, fev. 2009.

29 ORNELLAS, L.H. Técnica dietética, seleção e preparo de alimentos. 8 ed. São Paulo: ATHENEU, 2007. p. 276.

30 OSAWA, C.C. et al. Avaliação físico-química de bolo de chocolate com coberturas comestíveis à base de gelatina, ácido esteárico, amido modificado ou cera de carnaúba. Ciênc. Tecnol. Aliment., Campinas, v.29, n.1, p.92-99, jan./mar. 2009.

31 PAN, A. et al. Effects of a flaxseed-derived lignan supplement in type 2 diabetic patients: a randomized, double-blind, cross-over trial. Plos one, Shanghai, v.2, n.11, p. 1148-1158, Nov. 2007.

32 PHILIPPI, S.T. Nutrição e técnica dietética. 2. ed. São Paulo: Manole, 2006. p. 390.

33 ROSA, C.S. et al. Elaboração de bolo com farinha yacon. Ciência Rural, Santa Maria, v.39, n.6, p.1869-1872, set. 2009.

34 [SALES, R.L. Efeitos do amendoim e da linhaça no perfil lipídico, composição corporal e processo inflamatório em indivíduos com excesso de peso. 2009. 172 f. Dissertação (Mestrado em Ciência e Tecnologia de Alimentos) Universidade Federal de Viçosa, Viçosa, 2009.

35 SILVA, A.S.S. et al. Avaliação da resposta glicêmica em mulheres saudáveis após a ingestão de yacon (Smallantus sonchifollius) in natura, cultivadas no estado de Santa Catarina - Brasil. Alimentos e Nutrição, Araraquara, v.17, n.2, p.137-142, abr./jun. 2006.

36 SILVA, S.M.C; MURA, J.D.P. Tratado de alimentação, nutrição e dietoterapia. São Paulo: Roca, 2007. p. 561-570.

37 SILVA, F.M.; MELLO, V.D.F. Índice glicêmico e carga glicêmica no manejo do diabetes melito. Rev. HCPA, Porto Alegre, v.26, n.2, p.73-81, ago. 2006.

38 SILVA, J.B. et al. Utilização tecnológica de semente de abóbora na elaboração de biscoitos fonte de fibra alimentar e sem adição de açúcar. Rev. Bras. Tecn. Alim., Ponta Grossa, v.4, n.1, p.58-71, 2010.

39 STONE, H.S.; SIDEL, J.L. Sensory evaluation practices. San Diego: Academic Press, 1993. p. 338.

40 Tabela Brasileira de Composição de Alimentos (TACO). Campinas: Núcleo de Estudos e Pesquisas em Alimentação/ Universidade Estadual de Campinas, 2006.

41 World Health Organization (WHO). Report of a Joint FAO/WHO Expert Consultation. Diet, nutrition and the prevention of chronic diseases. Geneva, 2003. (Technical Report Series). 